This article was downloaded by: [Australian National University Library]

On: 20 January 2009

Access details: Access Details: [subscription number 907447645]

Publisher Routledge

Informa Ltd Registered in England and Wales Registered Number: 1072954 Registered office: Mortimer House, 37-41 Mortimer Street, London W1T 3JH, UK

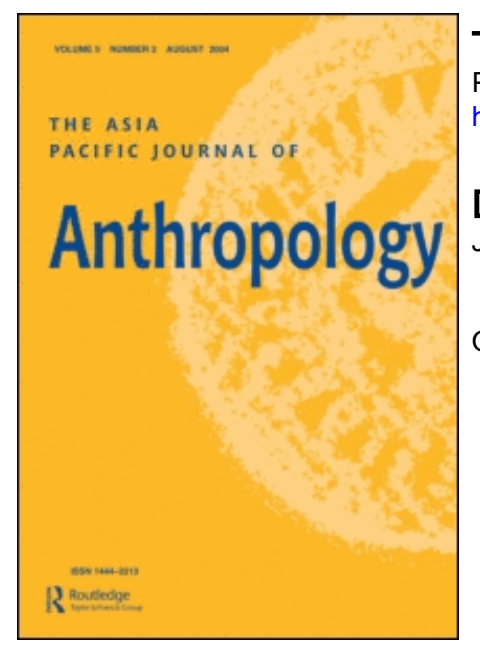

The Asia Pacific Journal of Anthropology

Publication details, including instructions for authors and subscription information:

http://www.informaworld.com/smpp/title content=t713689832

\title{
Douglas Miles and Borneo
}

Jennifer Alexander

Online Publication Date: 01 September 2008

To cite this Article Alexander, Jennifer(2008)'Douglas Miles and Borneo',The Asia Pacific Journal of Anthropology,9:3,189 — 197

To link to this Article: DOI: $10.1080 / 14442210802251639$

URL: http://dx.doi.org/10.1080/14442210802251639

\section{PLEASE SCROLL DOWN FOR ARTICLE}

\footnotetext{
Full terms and conditions of use: http://www.informaworld.com/terms-and-conditions-of-access.pdf

This article may be used for research, teaching and private study purposes. Any substantial or systematic reproduction, re-distribution, re-selling, loan or sub-licensing, systematic supply or distribution in any form to anyone is expressly forbidden.

The publisher does not give any warranty express or implied or make any representation that the contents will be complete or accurate or up to date. The accuracy of any instructions, formulae and drug doses should be independently verified with primary sources. The publisher shall not be liable for any loss, actions, claims, proceedings, demand or costs or damages whatsoever or howsoever caused arising directly or indirectly in connection with or arising out of the use of this material.
} 


\section{Douglas Miles and Borneo Jennifer Alexander}

In 1976, Douglas Miles published a book entitled Cutlass and Crescent Moon based on research carried out in South Borneo in the early 1960s. I take up some of the themes of that work to provide a narrative account of trade, barter and exchange across the Indonesian-Malaysian border on the upper Balui River of Sarawak in the last decades of the 20th century. Doug supervised my PhD thesis on rural commodity markets in Java for a short period and the advice he gave at that time was crucial, not only for the development of the thesis, but also for ensuing publications. The gist was that all research detail is important, but that one should not lose track of the main theme. In other words, good ethnographic writing should paint both the big picture and the small.

Keywords: Borneo; Trade; Barter; Exchange; Ethnicity; Penan; Kayan; Chinese; Sarawak; Kalimantan

In the evocatively titled Cutlass and Crescent Moon, Douglas Miles, in the space of less than 200 pages, laid the foundation for discussions of ethnicity, as well as social, religious, economic and political change within the upper Mentaya River region of Central Kalimantan in Borneo. His primary thesis was to explain why Ngadju Dayak became Bandjarese Malay, a process of assimilation he discussed in the context of three social systems: the tribal community, the peasant market centre, and the nation state (Miles 1976, p. 140).

In this essay, I touch on some of the issues discussed in Chapters 3 and 4 of Doug's pioneering work (Miles 1976) to provide a narrative account of trade, barter and exchange across the Indonesian-Malaysian border on the upper Balui River of Sarawak. There are two reasons for this: the first is that Doug was one of a series of people who supervised my $\mathrm{PhD}$ dissertation; and the second is that one of his other students, Peter Kedit, proposed that I carry out a study of Belaga Bazaar on the Rejang River.

Correspondence to: Dr Jennifer Alexander, Department of Anthropology, Research School of Pacific and Asian Studies, The Australian National University, Canberra, ACT 0200, Australia. Email: jennifer.alexander@anu. edu.au 
Doug supervised my $\mathrm{PhD}$ dissertation on rural commodity markets in Java for a few brief months between field trips in 1982. During this time, Doug had only one opportunity to look at my work. On this occasion I gave him a draft chapter on 'Buying Chillies'. Sometime later I had a meeting with Doug and he wryly remarked that my draft chapter told him more about chilli production than anyone may reasonably want to know. I felt somewhat mortified about my obsession with detail, but then, much to my surprise, Doug rather impishly prodded me for further details, that is, about chilli marketing, not production. Doug was the second in a series of supervisors - the first in the Anthropology Department - to help me disentangle the plethora of detail that was to become, first, a dissertation (Alexander 1984), then a paper based on the core chapter that Doug had advised me on (Alexander 1986) and finally a book (Alexander 1987).

Doug was also one of a series of supervisors who helped an Iban $\mathrm{PhD}$ student, Peter Kedit, to the completion of his degree in 1987. He was the second Iban to obtain a PhD in anthropology and one whom Doug regarded as part of the emerging 'New Guard' (Miles 1994a, p. 2, fn 3). Peter's dissertation was published six years later, after he had written an exploratory paper on the gender aspects of Iban bejalai (Kedit 1991, 1993). At the time of Peter's graduation, he was Government Ethnologist for the Sarawak Museum and later became its Director. It is thanks to Peter (and, indirectly, Doug) that I was able to carry out research in Sarawak in north Borneo. At a time when academic jobs were becoming increasingly scarce, I agreed to participate in a study organised by the Sarawak Museum. The plan was mooted that, given my experience of markets in rural Java, it would be appropriate for me to carry out a study of Belaga Bazaar on the Rejang River. When the plan fell through I-with a QEII fellowshiparrived in Sarawak to carry out research on demographic change in a Kayan longhouse community on the upper Balui. In the interim, the studies organised by the museum had been reinstated and we reached a compromise on the location of the study, a Kajang rather than a Kayan longhouse, so that I could prepare a report for the Museum as well as carry out my own research. The experience was invaluable in gaining many methodological skills, a wider perspective on the region and the significance of political as well as religious change - the very issues that were so crucial to Doug's study. Here, however, I attempt to redress my failure to carry out a study of Belaga Bazaar, by reflecting on trade from the point of view of the longhouse rather than the bazaar and by trying to capture some of Doug's story-telling ability.

\section{The Small Picture}

My interest in local trade, barter and exchange was initially stimulated by my longhouse father, Taman Urah, in whose longhouse apartment I resided. In the corner of the family apartment or tilung was a huge pile of trade goods acquired from the Penan. When questioned about their provenance, Taman Urah, with a little prodding - because he was a shy, reserved man, but one with a sly wit - puckishly retold stories about his father's and grandfather's arduous journeys into the interior 
to engage in barter trade with the Penan, the hunter-gatherers living deep in the forest. Taman Urah took some joy in telling me about his grandfather's and father's sojourns with the Penan, in the process of which the former married a Penan woman and thus established a long-lasting link with them.

In Kayan, the lingua franca of Belaga District, this trading activity is called na'ai Punan, 'going to the Penan', the general term for the formerly nomadic huntergatherers. Na'ai Punan places an emphasis on the journey and people, rather than the trade itself. It was only on further prompting that I gained some idea of the parameters of this barter trade: the relationship of the middleman trader to his towkay, or supplier, and the wider context of transactions linking Penan with Kayan, other Orang Ulu and even Iban in a Borneo-wide trading system (see also Alexander 1992, pp. 214-5; Alexander \& Alexander 2002, pp. 458-9; Armstrong 1998).

My desire to go on a Penan trading expedition was further fuelled on the levu or the public gallery of the longhouse, by the stories of Uyong Doh a young mother, still breastfeeding her youngest child. Uyong Doh, so-named because she had lost her first born child, bore the scars of a life on the Balui River-she was minus a toe accidentally removed when pounding rice with mortar and pestle and lacked the top row of front teeth from an inappropriate, and perhaps inadequate, diet. When she remembered, she inserted a prosthesis, but she frequently forgot.

I regarded Uyong Doh as a kindred spirit. She was married to Uyong Kulleh, originally from Uma Belor, a Kayan longhouse community downriver. He was the son of a towkay named Asai and a high-ranking Kayan. His mother died of dysentery a week after childbirth and Kulleh was adopted by his mother's sister and took on her husband's name, Dieng. When his adoptive mother in turn died, he and two of her children were adopted by another high-ranking couple regarded as close kindred living at Long Pangai, my field site. Uyong Kulleh, following the tradition of many elite Kayan, is a committed trader and, since 1984, has preferred to spend much of his time living alongside the Penan at Long Lusong. First he worked as a cook at the school, trading only part-time, and later he opened his own trade store selling biscuits and beer at the settlement and collecting the diverse products of Penan labour. Uyong Doh guarded the home apartment (tilung), but occasionally accompanied other traders visiting the Penan Lusong on the Linau River, a tributary of the Balui. Uyong Doh vividly brought to life the journey: trekking through the forest, travelling by longboat for lengthy stretches of relatively calm waters, unloading the boat when reaching an impassable rapid and clambering over rocks, leaving men to haul the longboat to a position further upriver. She always spoke in such glowing terms of the healthy mountain environment at Long Lusong, the plentiful supply of vegetables and jungle fruits, the fresh wild boar and the friendly open people with pale skin.

Although Uyong Doh placed an emphasis on the journey and the location of the Penan Lusong ('Lusong' means 'above the rapids') settlement, the male traders who regularly participated in na'ai Punan, when pressed, elaborated on their revolving credit relationships with towkay in Belaga Bazaar and elsewhere, the costs of their 
middleman trade and the mainly barter trade they conducted with Penan individuals, with whom they had regular trading links. Each of the elite headmen in the region had contact with a number of Penan communities living on more remote rivers. Taman Urah once invested Ringgit Malaysia (RM) 300 on goods such as sugar, soap, noodles and satin shorts, which he exchanged for 82 small rattan backpacks and 2 rattan mats. He acquired all these goods by small-scale barter exchange with the Penan. The exception was an expensive toy he had bought in the local bazaar for RM25 and sold to a Penan for RM50. He anticipated obtaining around RM10 for the smallest of the backpacks and RM13 for the larger from his regular towkay in Belaga Bazaar.

By 1990, Taman Urah no longer went on trading expeditions, but three of his former trading companions - all mature men - went with a group of Kayan from Uma Belor in 1992 for a trip lasting between ten and twenty days. Some of the traders returned earlier than others because their Penan trading partners had completed their quotas in a shorter time. On their return, one sold thirty backpacks to the headman wholesale for RM360. The headman intended to sell them to his son, William Dieng Nyipa Pasu, who worked for the Sarawak Economic Development Corporation. In the past, Taman Urah's father and grandfather were usually away for two months at a time, occasionally even as long as six months. But the journey was longer and more arduous then.

I did not articulate my desire to accompany my longhouse father, Taman Urah, on a trading trip to the Penan. I was fearful of being an encumbrance on a predominantly male journey and, instead, asked him to acquire goods from the Penan, which I subsequently gave to my husband on my return home to Australia: a blowpipe, a hunter's rattan backpack and a working bushknife. The memories of Penan trade articulated by my father, his son Dieng and his trading expedition companions, and even by my mother, Tinieng Merieng, continued to engage me. On one occasion, Tinieng Merieng shyly informed me that she had once accompanied her husband on a Penan trading expedition, during the course of which she suffered a miscarriage. Unfortunately, I lacked the time to make a journey of my own. I did, however, observe trade, barter and exchange within and even beyond the longhouse, in the household kedai that I looked after from time to time, and the occasional trip to the downriver market towns of Belaga, Kapit, Sibu and Kuching, each of which have their parallel in Doug's account of trade in Central Kalimantan, where he did his research in the 1960s.

Many longhouse communities on the Balui had a small trade store (kedai) dealing in a range of durable commodities (e.g. soap, biscuits, sugar, noodles, cigarettes and sardines, the generic term for all canned goods, particularly fish) (cf Miles 1976, p. 35). At Long Pangai, the main store was operated by my mother, Tinan Merieng, but a number of other women occasionally opened a stall for a short while. These stalls tried to operate on a strictly cash basis, but very occasionally credit was permitted and, sometimes, carefully noted in a book. More rarely, a quantity of rice, for example, was exchanged for a relatively low priced commodity (cf. Alexander \& 
Alexander 1995). It was here at first hand that I witnessed transactions between the locals and the Penan from Long Belangan upriver from Long Pangai. This had an element of barter trade. As each item was acquired, the Penan girl handed over the required amount of cash; then, if there was any cash remaining, went on to purchase another item. In 2006 when I visited the longhouse after resettlement in Sungai Asap, I again witnessed the same procedure. A young man I had first known as an obstreperous teenager of sixteen had recently, after divorcing two previous spouses, married a young Penan girl. Solicitously, he watched and guided his young wife as she acquired first a packet of Twisties, then a bundle of sweets and then two eggs, each in a different and discrete transaction.

In other longhouse communities, kedai were sometimes operated by a Chinese towkay or even a Malay trader, who may have married a local. Accounts at these stores were more complex and not infrequently involved large-scale debt relationships that mirrored those found in the market towns further downriver (cf. Miles 1976, pp. 15-17, 21-3). These stores were generally more ambitious in scale and, in addition to providing basic merchandise, bulked locally produced commodities, including cocoa, coffee, jungle produce and, in more recent times, large river fish and wild boar stored in a freezer. Although Taman Urah had once bulked all these commodities for towkay in the Belaga Bazaar, by 1987 the collapse of the public longhouse generator had confined the products to non-perishables.

In the longhouse, I witnessed all forms of transaction: trade, barter and exchange not only between longhouse residents, but also between longhouse residents and the Penan from Long Belangan upriver from Long Pangai. Those with limited financial resources bartered rice or tobacco for sugar, mie or canned sardines. Those with limited experience of financial transactions - both longhouse residents and the Penan-paid for things piecemeal rather than in toto. For example, they may purchase and pay for a packet of sugar, then a packet of tobacco, then a cake of soap. But modern commodity transactions occurred alongside these simpler forms of exchange. The Penan, as great hunters and skilled bushwalkers, sometimes came to Long Pangai to sell wild boar by piece and also by weight, establishing the price prior to the exchange. All three forms of transaction clearly identify the longhouse residents and the Penan as active agents in the exchange process.

Even in the early days of fieldwork, a regular stream of traders, Chinese towkay, Indian merchants and traders of hybrid ethnicity, made their way up river and even down from Indonesia, by tongkang (open cargo boat), longboat and even a recently introduced express service. The most frequent and long-term traders on the river were Chinese towkay from Belaga, who travelled upriver by tongkang to buy up cocoa, pepper and jungle produce (cf. Miles 1976, pp. 17-21, 28). My field notes record one visit (29 May 1987):

We had a visit from a Chinese towkay who was travelling upriver. He stopped by Long Pangai hoping to buy up cocoa. He carried some scales with him - the kind that weigh up to $15 \mathrm{~kg}$. So he obviously buys in fairly small lots. He wore a bumbag round his waist but apparently didn't part with any cash as no sales were made. And 
on the 27/6/87 another, a Kayan-Chinese towkay wearing a heavy gold necklace, called in to see if there was any cocoa for sale and purchased five sacks - one only half full, the others $2 / 3$ full. Query: the same man or a different one? Was he on his way downriver?

I was later able to answer the questions posed in my early notebooks. Towkay sometimes travelled to the headwaters of the Balui, past Long Bulan and Long Jawe as far as Long Busang, if the waters were running their way. A towkay dropped in on the various longhouse communities on the way upriver, informing people of his possible return in a week or two. Those desperate for cash, or with only small quantities for sale, often took the opportunity to trade. Most preferred to take their produce downriver in search of a higher price, or in association with a visit to a better-trained doctor or the purchase of a major household item, such as a generator.

In the early years of my fieldwork, an occasional longboat powered with outboard motors travelled down to Belaga for some special purpose. The trip was usually planned in a very discrete manner, because those organising the journey did not want any freeloaders; they were happy enough to take close relatives for free or a nominal fee, but wanted other travellers to help pay for the high cost of petrol and the manpower involved in the travel. They left in the early hours of the morning with one or two men handling the outboard motors and a watchman at the bow keeping a close lookout for logs and noting the placement of rocks and boulders submerged beneath the surface. Upon arrival in Belaga, which bore a strong resemblance to the small river port of Sampit (Miles 1976, p. vii), the passengers disembarked at the jetty and climbed the steps to the row of Chinese shophouses. Taking a brief respite, they visited a Chinese café for the ubiquitous noodles, either fried or in soup, according to taste, and Chinesestyle coffee, brewed in a cloth bag and served either with or without condensed milk (kopi and kopi $O$ in local parlance). If a return trip was planned for the same day, travellers went on a frantic shopping spree, buying up food supplies, clothing and household goods, before the journey home mid-afternoon. Those planning on staying a night or two before their return stayed with friends or relatives in the Malay kampung downriver from the shophouses, near the boarding school. If not, they would stay in accommodation provided by the local authorities for river travellers.

These observations indicate the nature of local trade during the final decades of the 20th century and have much in common with the many other small and relatively remote communities of Sarawak, and even with their counterparts across the Indonesian border in places like Tumbang Gagu, Kuala Karis (the other name for Kuala Kuayan), Sampit and Banjarmasin in Kalimantan, where Doug did his research.

\section{The Big Picture}

What can be defined as the 'big picture' has changed. The final chapters of Doug's Cutlass and Crescent Moon (Miles 1976) documents some of the issues that have become so pressing in regional politics of the present. Doug Miles painted a big picture for his time with his analysis of a regional political economy in Central 
Kalimantan. This was based solely on his own research. Research projects now require teams of workers and books playing on larger themes are usually edited collections (Winzeler 1997; Wadley 2005a; Biersack and Greenberg 2006).

The volume edited by Wadley (2005), for example, examines economic, political and social dimensions of change and continuity throughout the island of Borneo: Indonesian Kalimantan, the Malaysian states of Sarawak and Sabah and the independent kingdom of Brunei. Because of my interest in trade, I single out the contributions by Tagliacozzo (2005), Sellato (2005) and Potter (2005), who all variously address the theme of the relationship between distant and local economies. Other sections of the work, including Wadley's (2005b) own chapter, examine colonial and national resource politics and social transformations. For example, George Appell (2005), who has devoted so much of his time, money and scholarly activity to Borneo studies documents a damning case of the impact of Western ideology on the Rungus of Sabah over the forty years had had conducted research there.

When I last met Doug at the Australian Anthropological Society Conference held in Canberra 2007, he, like Appell, expressed dismay about the development plans and policies which have successively led to destructive changes in indigenous societies and environments and was intensely involved in discussions with younger scholars presenting papers on northern Thailand and Laos, the region where he did his PhD research. He himself presented a paper in a session entitled 'Topics in Contemporary Anthropology' (Miles 2007).

In conclusion, I refer to the inaugural issues of ASSESS, in which Doug wrote not only the editorial (Miles 1994a), but also one of the main articles discussing the foundation works of research on the other side of the border in Sarawak, Malaysia, in a special volume entitled 'Australian Anthropology in Borneo: The New Guard' (Miles 1994b). In the editorial, he examines the issue that the indigenous anthropologists are the new guard and raises the possibility that a further generation of Australian anthropologists may yet be included among that number. Mary Hawkins is one of them. Although she did only a couple of undergraduate courses with Doug, she later carried out fieldwork in South Kalimantan for her PhD in the 1980 s and, since then, has cited his work in all her publications on Borneo (Hawkins 1989 , p. 210, fn 1; 2000, 2005, in press). She has built upon Doug's discussions of ethnicity and the emergence of a pan-Kalimantan Dayak identity, within which the actors identify themselves as Dayak; regionalism, which examines events on a broad scale rather than the small units of social organisation traditionally studied by ethnographers; Islamisation and Christianisation of local Dayak; and conflict over resources and the concomitant violence in the context of Indonesian Kalimantan, only one part of Borneo, but definitely the largest - an admirable legacy for such a key figure in Borneo Studies.

\section{Acknowledgements}

Fieldwork in Sarawak was funded by a number of Australian Research Council (ARC) grants, all of them jointly with Paul Alexander and one in association with Mary 
Hawkins. The main fieldwork at Long Pangai was carried out from May to October, 1987, and from April until the end of July, 1988. I am grateful to the ARC, which funded the research under a QEII Fellowship at Macquarie University, and the Sarawak Museum for facilitating research. I wish to thank the two anonymous peer reviewers, as well as Rosita Henry, Kathy Robinson and Margret Wijeyewardene for comments on an earlier draft.

\section{References}

Alexander, J. (1984) Pasar, Pasaran, Trade, Traders and Trading in Rural Java, PhD Thesis, University of Sydney, Australia.

Alexander, J. (1986) 'Information and price setting in a rural Javanese market', Bulletin of Indonesian Economic Studies, vol. 20, no. 1, pp. 88-112.

Alexander, J. (1987) Trade, Traders and Trading in Rural Java, Oxford University Press, Singapore.

Alexander, J. (1992) 'Must ascribed status entail inequality? Reproduction of rank in Lahanan society', Oceania, vol. 62, pp. 207-26.

Alexander, J. \& Alexander, P. (1995) 'Commodification and consumption in a Central Borneo community', Bijdragen tot de Taal-, Land-en Volkenkunde, vol. 151, no. 2, pp. 179-93.

Alexander, J. \& Alexander, P. (2002) 'Gender and ethnic identity among the Lahanans of Sarawak', in Tribal Communities in the Malay World: Historical, Cultural and Social Perspectives, eds C. Chou \& G. Benjamin, The Institute for Asian Studies, Leiden/Institute for Southeast Asian Studies, Singapore, pp. 457-74.

Appell, G. N. (2005) 'Dismantling the cultural ecosystem of the Rungus of Sabah, Malaysia', in Histories of the Borneo Environment: Economic, Political and Social Dimensions of Change and Continuity, ed. R. L. Wadley, KITLV, Leiden, pp. 213-43.

Armstrong, R. (1998) 'Insufficiency and lack: between production and consumption in a longhouse economy, 1909-1996', Man, vol. 4, no. 3, pp. 511-30.

Biersack, A. \& Greenberg, J.B. (eds) (2006) Reimagining Political Ecology. Duke University Press, Durham \& London.

Hawkins, M. (1989) 'Slametan in South Kalimantan', in Creating Indonesian Cultures, ed. P. Alexander, Oceania Publications, Sydney, pp. 159-74 (+ p. 210 fn).

Hawkins, M. (2000) 'Becoming Banjar: identity and ethnicity in South Kalimantan, Indonesia', The Asia Pacific Journal of Anthropology, vol. 1, no. 1, pp. 24-36.

Hawkins, M. (2005) “Those murderous Dayak": local politics, national policy, ethnicity and religious difference in Southern Kalimantan, Indonesia', Australian Religion Studies Review, vol. 18, no. 2, pp. 175-95.

Hawkins, M. (in press) 'Violence and the construction of identity: conflict between Dayaks and Madurese in Kalimantan, Indonesia', in The Politics of the Periphery in Decentralised Indonesia: Geographical and Social Perspectives, eds M. Sakai, J Walker \& G. Banks, National University of Singapore Press, Singapore.

Kedit, P. M. (1991) “"Meanwhile, back home ..." Bejalai and their effects on Iban men and women', in Female and Male in Borneo: Contributions and Challenges to Gender Studies, The Borneo Research Council Monograph Series, Volume 1, Ashley Printing Services, Shanghai, pp. 295316.

Kedit, P. M. (1993) Iban Bejalai, Ampang Press for the Sarawak Literary Society, Kuala Lumpur.

Miles, D. (1976) Cutlass and Crescent Moon: A Case Study of Social and Political Change in Outer Indonesia, Southwood Press, Sydney.

Miles, D. (1994a) 'Editorial: The changing of the guard? Australian anthropology in Borneo [circa 1955-1994/circa 1987-1994]', ASSESS, vol. 1, pp. 1-4. 
Miles, D. (1994b) 'Monkey-business in the anthropology of Sarawak: shamanic actuality versus sociological illusion in Dayak politics', ASSESS, vol. 1, pp. 70-96.

Miles, D. (2007) 'Beyond Ockham's Razor in the Northern Thai Highlands: Further philosophical issues in the anthropology of development and Australian Foreign aid', Australian Anthropological Society annual meeting, Canberra, ACT.

Potter, L. (2005) 'Commodity and environment in colonial Borneo', in Histories of the Borneo Environment: Economic, Political and Social Dimensions of Change and Continuity, ed. R. L. Wadley, KITLV, Leiden, pp. 109-33.

Sellato, B. (2005) 'Forests for food, forests for trade - between sustainability and extractivism', in Histories of the Borneo Environment: Economic, Political and Social Dimensions of Change and Continuity, ed. R. L. Wadley, KITLV, Leiden, pp. 61-86.

Tagliacozzo, E. (2005) 'Onto the coast and into the forests', in Histories of the Borneo Environment: Economic, Political and Social Dimensions of Change and Continuity, ed. R. L. Wadley, KITLV, Leiden, pp. 25-59.

Wadley, R. L. (ed.) (2005a) Histories of the Borneo Environment: Economic, Political and Social Dimensions of Change and Continuity, KITLV, Leiden.

Wadley, R. L. (2005b) 'Boundaries, territory, and resource access in West Kalimantan, Indonesia, 1800-2000', in Histories of the Borneo Environment: Economic, Political and Social Dimensions of Change and Continuity, ed. R. L. Wadley, KITLV, Leiden, pp. 137-57.

Winzeler, R. L. (ed.) (1997) Indigenous People and the State: Politics, Land and Ethnicity in the Malayan Peninsula and Borneo, Monograph 46, Yale Southeast Asia Studies, New Haven. 